\title{
Systematic Review of Meaning-centered Interventions for Adolescents
}

\author{
Young Sook Lim ${ }^{1}$, Kyung A Kang ${ }^{2}$ \\ ${ }^{1}$ Department of Nursing, Graduate School of Sahmyook University, Seoul; ${ }^{2}$ Department of Nursing, Sahmyook University, Seoul, Korea
}

Purpose: This study analyzes meaning-centered intervention studies conducted in Korea and abroad to compare and confirm their characteristics and results. Methods: A literature search using keywords in English and Korean was performed using nine electronic databases in December 2017. Search participants included adolescents, and interventions conducted in meaning-centered intervention studies were selected for evaluation. A Risk of Bias Assessment tool for non-randomized studies was used for quality assessment. Results: All studies were based on quasi-experimental designs. The semantic intervention included topics such as freedom, choice, responsibility, pain, death, finding value of life, purpose and meaning of life, and becoming a master of my life. All studies used logotherapy, and included meaningful interventions that influenced the meaning and purpose of the life of adolescents. The life satisfaction of adolescents changed significantly when there is a positive and open relationship with their parents. Therefore, an educational program for parents based on meaning therapy is desperately needed. Conclusion: Meaning-centered interventions were found to be effective interventions for exploring the meaning of life not only for adolescents with problems but also for healthy youth, and as such could be used as basic data for the development of an appropriate intervention for enhancing their life.

Key words: Adolescent, Literature review

\section{Corresponding author Kyung A Kang \\ https://orcid.org/0000-0002-3799-9554}

Department of Nursing, Sahmyook University,

815 Hwarang-ro, Nowon-gu, Seoul 01795, Korea

TEL +82-2-3399-1585 FAX +82-2-3399-1594

E-MAIL kangka@syu.ac.kr

Received May 2, 2018 Revised Jun 1, 2018 Accepted Jun 8, 2018 (a) This is an Open Access article distributed under the terms of the Creative Commons Attribution NonCommercial License (http://creativecommons.org/licenses/by-nc/4.0/) which permits unrestricted noncommercial use, distribution, and reproduction in any medium, provided the original work is properly cited.

\section{INTRODUCTION}

Adolescence typically from 11 to 21 years of age describes the transitional stage from childhood to adulthood characterized by fast physical changes, psychological development and hormonal changes, conflicts and disobedience with parents, sexual interest, self-consciousness, concerns about the future, and social relationships [1]. Adolescents at this stage experiment with diverse roles to explore the important duty of identity development towards the ultimate goal of integrating self-identity factors and resolving conflicts [1]. However, many adolescents fail to achieve autonomy and independence at this critical stage of human development due to the fast pace of modern society, lack of communication with working parents, parents' pressure to achieve good grades, overprotection and high expectations from parents, and growing up in a competitive environment that emphasizes success [2]. They may also find it difficult to discover the values of life and self-identity, be deprived of the time and environmental support needed to contemplate self-awareness and develop future plans [2]. According to a Statistics Korea 2018 report [3], the leading cause of teenager death was suicide, with $36.4 \%$ of adolescents reporting that they had no clear life goal; $46.4 \%$ 
said that they mostly talk only about school with parents, and $25 \%$ had experienced sadness or severe depression that stopped them from doing daily activities. Yeom [4] found that the subjective happiness score among Korean adolescents stood at 82 (out of 100 points), the lowest among the 22 OECD members participating in the study, and many thought good school grades and money were the prerequisites for happiness [4].

A meaning-centered approach for research investigates ways to enhance meaning, spiritual well-being, and the quality of life, and is rooted in the writings of Frankl [5], a psychologist and holocaust survivor who authored 'Man's search for meaning' Frankl suggested that human beings are motivated mainly by creating meaning in their existence, and that they are capable of doing so even when going through the deepest of pains. This process helps reduce pain and bring about psychological happiness in the future [6]. The intent of this type of intervention is to strengthen participants' meaning of life and spiritual well-being by helping them realize the importance of their choice in attitude, ability to connect with life, and understand their past and future legacy [6].

Meaning of life, the core concept of the meaning-centered approach, is about searching for what an individual believes to be the most valuable and meaningful, which could guide the direction of their life [5,7]. The search for meaning of life is indeed a critical matter at any stage of a person's life, but is desirable to start at the adolescent stage where one's self-concept and values start to develop and consolidate, so that they can find purpose meaning in their life, which is essential for planning a healthy and rewarding life [8]. If a person manages to establish meaning and purpose in adolescence, they are likely to lead a future life with concrete goals, solid self-concept, and self-esteem, with spiritual well-being and less anxiety and stress. On the other hand, failure to form a stable identity and life goals during this period could lead to a loss of confidence, depression, helplessness, disillusionment, alienation, meaninglessness, negative attitudes, and/or delinquency [1]. Therefore, educational and social support should be provided to encourage adolescents to promote satisfaction and meaning, so that they can understand the dignity, meaning, and values of life and stay more positive, productive, and proactive [8].

Previous studies pertaining adolescent life have mainly focused on low-income youths [9], school drop-outs [10], and children from multicultural families [11]. The low subjective life satisfaction among these youths was considered to be evidence that they do not understand the real meaning of life. Not until recently have researchers started to pay attention to lives of healthy adolescents and have studied the determinants of quality of life in Korean adolescents [12], the relation- ship between the goals and life satisfaction in adolescents [13], effects of logotherapy on life-esteem on older elementary school-age children [14], experiences of meaning in life among elementary school students [8], and development of a finding meaning in life program in the form of a compact disc (CD) [15]. However, there has been no research investigating meaning-centered education and support for average adolescents who are living through the current materialistic and honor-centered social environment to bring about meaningful changes and spiritual well-being.

This study aims to analyze and compare previously conducted meaning-centered intervention studies and to then suggest a direction for developing education programs to help healthy adolescents establish value-based life goals and lead a more meaningful life.

\section{Objectives}

The purpose of this study is to analyze meaning-centered intervention studies conducted in Korea and abroad and then compare these characteristics and results. To achieve this task, the first concrete goal is to understand the attributes and status of existing meaning-centered intervention studies with regards to adolescents. Then, the second goal is to identify the content, methods, and effects of those studies.

\section{METHODS}

\section{Research Design}

A systematic study of literature was performed to understand the status of meaning-centered intervention studies and to identify their characteristics and effects.

\section{Search and Selection of Studies}

\section{1) Literature search}

Search for literature pertaining to meaning-centered intervention programs for adolescents was carried out between December 2017 and February 2018, after approval by the Institutional Review Board of S University (IRB No. 2-1040781AB-N-01-201833HR). Search criteria was decided upon beforehand, based on a combination of terms relevant to adolescents $(\mathrm{P})$ and meaning-centered intervention (I) and the study design. First, the MeSH controlled vocabulary list for meaning-centered intervention was confirmed on MEDLINE, and included all MeSH words. Search keywords were then created based on subject keywords from relevant abstracts. MeSH vocabulary was used for searches conducted in the Cochrane Library CENTRAL and CINAHL databases, and the same 
method was used on the EMBASE after confirming controlled vocabulary at EMTREE. For Korean databases, keywords consisted of combined words for logotherapy and meaning-centered intervention. Key electronic databases of Korea and abroad were used, as well as CINAHL, the largest source for nursing and allied health journals. Overseas literature searchers were mainly conducted in MEDLINE, EMBASE, and Cochrane Library CENTRAL, and the sources of domestic literature included the KMbase, RISS, Nanet, KISS, and NDSL databases. Searches were limited to Korean and English language results, and all literature available from each database up to February 2018.

\section{2) Selection and compilation of data}

Search results were reviewed to avoid redundancy using the Reference Management Database (Refworks). Initial screening was performed based on title and abstract, followed by a review of the full content according to preset criteria. Each researcher conducted the search and review independently, and final resources were determined via discussions. Final sources were extracted from the streamlined list. The consistency of extracted data was ensured using a pre-study, with the original content being reviewed for final determination when inconsistencies were found.

\section{3) Criteria for literature selection and elimination}

Literature accessible for full text and published in English or Korean were selected from among the available experimental studies on meaning-centered intervention for adolescents. Non-experimental studies and conference programs were excluded. Dissertations were included in order to provide more diversity in the intervention strategies, with published research papers chosen over dissertations in the case of redundancy of content. Two of the team members independently performed the selection and elimination process, and disagreements were resolved via discussions.

The total number of search results from the four overseas databases was 7,386: 4,343 from EMBASE, 1,107 from CINAHL, 1,012 from PubMed, and 924 from Cochrane Library CENTRAL. The number of results from the five domestic sources totaled 1,754: 872 from RISS 872, 536 from NANET, 242 from NDSL, 97 from KISS, and 7 from KMbase. Combined, the total literature search resulted in 9,140 papers. The list was shortened to 7,269 articles after redundancy elimination. After a review of titles and abstracts, 22 articles were found to be relevant to adolescence. The application of selection and elimination criteria were applied to 20 in which there was access to full text. Ultimately, 13 domestic studies were selected as final subjects, eliminating 7 articles that did not deal with a meaning-centered approach (Figure 1).

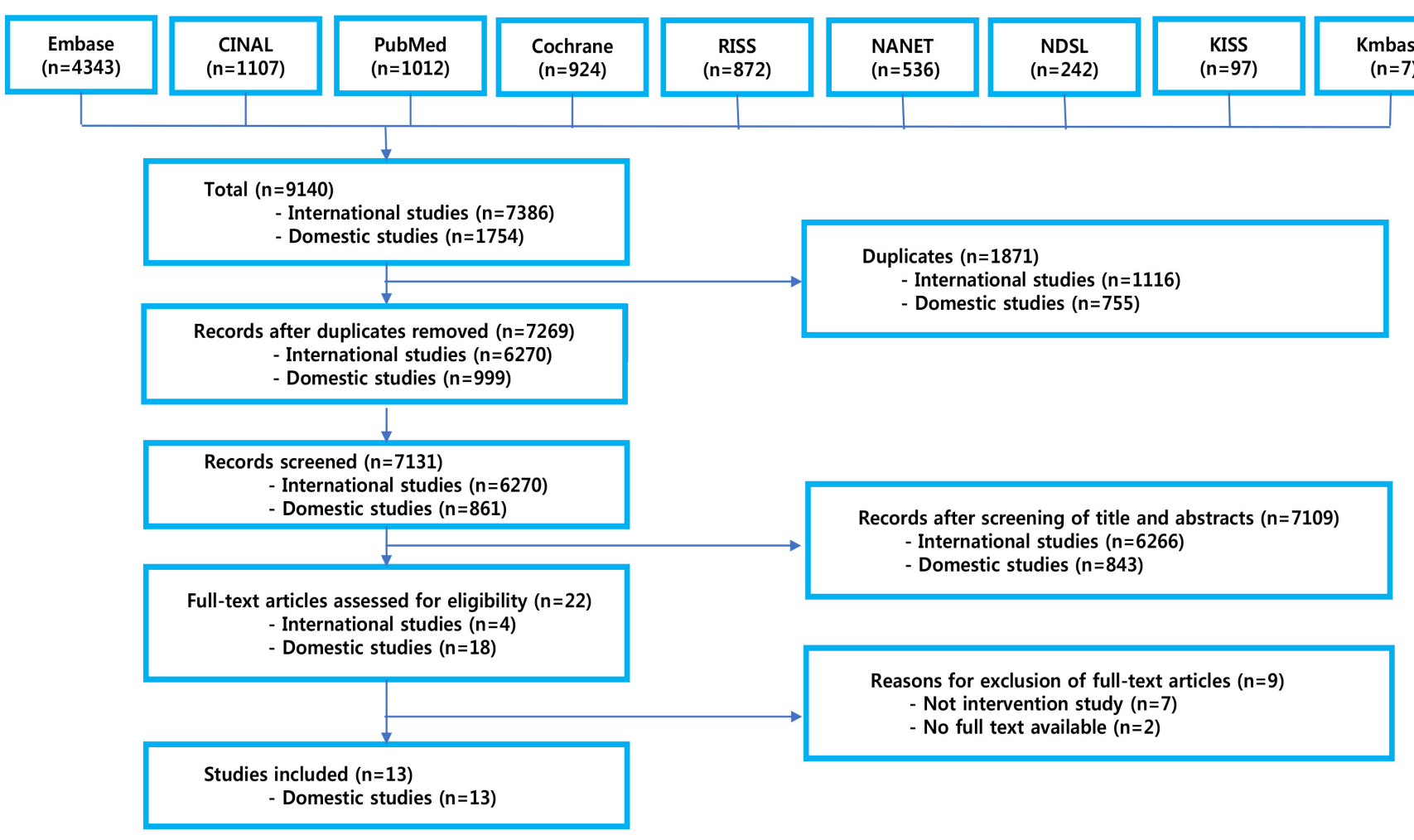

Figure 1. Flowchart of studies included from the database search. 


\section{Analysis Method}

A framework was developed to analyze the final 13 studies, and two researchers conducted independent evaluations of their target subjects, study design, intervention characteristics, and results. Intervention characteristics were categorized into individual and group interventions, targeting healthy and unhealthy subjects. Intervention styles were divided into either logotherapy-only or combined interventions, as meaning-centered interventions naturally involve the use of logotherapy. The analysis of these results consisted of measurement tools and outcome variables.

\section{Quality Evaluation of Selected Literature}

The quality of selected literature was assessed using the Risk of Bias Assessment tool for Non-randomized Studies (RoBANS). RoBANS contains eight domains, including comparability of participants, selection of participants, confounding variables, intervention exposure measurement, blinding for outcome assessment, and outcome evaluation, incomplete outcome data, and selective outcome reporting [16]. Two researchers independently scored each domain "low", "high", or "unclear" and, whenever there is a disagreement, came to a final conclusion after subsequent discussions (Table 1).

\section{RESULTS}

\section{General Attributes of Selected Literature}

The 13 selected studies were examined with regards to their participants, publication year, type of study, major field of researchers, study design, sample size, setting, and ethical considerations. Two studies had children in early adolescence as participants, eight studies targeted healthy adolescents in middle and high school, and three studies involved adolescents having cancer. One was published in 1999 and earlier, six between 2000 and 2009, and another six between 2010 and 2015. Seven studies were published in academic journals, whereas six were dissertations for master's degrees. Major fields for the researchers ranged from nursing (7 studies), education (4 studies), counselling psychology (1 study), and youth leadership (1 study). Only one of the studies adopted the "one group pre-posttest design" compared to the rest, applying the "nonequivalent control group pre-posttest design".

The total number of participants was 20 and under in three articles, 21 to 50 in seven articles, 51 to 100 in two articles, and 100 or more in one article. The average number of participants for the nonequivalent control group pre-posttest designs was 41.4, with 50 participants in the one group pre-posttest design. Interventions were performed in school settings for seven cases, followed by hospitals (3), churches (2) and community cen-

Table 1. Risk of Bias Assessment of Studies Included in this Study

$(N=13)$

\begin{tabular}{|c|c|c|c|c|c|c|c|c|}
\hline Author (year) & $\begin{array}{l}\text { Comparability } \\
\text { of participants }\end{array}$ & $\begin{array}{l}\text { Selection of } \\
\text { participants }\end{array}$ & $\begin{array}{l}\text { Confounding } \\
\text { variables }\end{array}$ & $\begin{array}{c}\text { Intervention } \\
\text { exposure } \\
\text { measurement }\end{array}$ & $\begin{array}{l}\text { Blinding for } \\
\text { outcome } \\
\text { assessment }\end{array}$ & $\begin{array}{c}\text { Outcome } \\
\text { evaluation }\end{array}$ & $\begin{array}{c}\text { Incomplete } \\
\text { outcome } \\
\text { data }\end{array}$ & $\begin{array}{l}\text { Selective } \\
\text { outcome } \\
\text { reporting }\end{array}$ \\
\hline Kang $(2006)^{1}$ & Low & Low & Low & Low & High & Low & Low & Low \\
\hline Kang et al. $(2013)^{2}$ & Low & Low & Low & Low & Low & Low & Low & Low \\
\hline Kang et al. $(2009)^{3}$ & Low & Low & Low & Low & Low & Low & Low & Low \\
\hline Lee $(1997)^{4}$ & Low & Low & Low & Low & Unclear & Low & Low & Low \\
\hline Lee $(2014)^{5}$ & Low & Low & Low & Low & Unclear & Low & Low & Low \\
\hline Lee $(2015)^{6}$ & Low & Low & Low & Low & Unclear & Low & Low & Low \\
\hline Jung $(2003)^{7}$ & Low & Low & Low & Low & High & Low & Low & Low \\
\hline Cho $(2000)^{8}$ & Low & Low & Low & Low & High & Low & Low & Low \\
\hline Choi $(2000)^{9}$ & Low & Low & Low & Low & High & Low & Low & Low \\
\hline Kang et al. $(2009)^{10}$ & High & Low & High & Low & High & Low & Low & Low \\
\hline Kang et al. $(2013)^{11}$ & Low & Low & Low & Low & Low & Low & Low & Low \\
\hline Kim et al. $(2011)^{12}$ & Low & Low & Low & Low & High & Low & Low & Low \\
\hline Kim et al. $(2000)^{13}$ & Low & Low & Low & Low & Unclear & Low & Low & Low \\
\hline
\end{tabular}


ters (1). Three of the articles acquired IRB approval, thereby meeting ethical standards (Table 2).

\section{Quality Assessment}

The RoBANS tool was used to evaluate the quality of the selected non-randomized studies (Table 1). In terms of "comparability of participants", one group pre-posttest design study included the same target group before and after intervention, whereas the nonequivalent control group pre-posttest studies had lower risk of bias. In the domain of the "selection of participants", all collected data prospectively, not selecting or eliminating participants arbitrarily, and maintained the same criteria and methods for both the subject and control groups. All studies except the one-group study controlled "confounding variables" by selecting control groups through homogeneity tests or covariate analysis. In terms of "intervention exposure measurement", all studies clearly presented the duration, frequency, and number of interventions. With regards to "blinding for outcome assessment", four studies were at high risk of bias by not clarifying their study process, with six studies confirmed to have been conducted directly by the research- ers. In terms of "outcome evaluation", all adopted tools that had already been validated for credibility and validity. In terms of "incomplete outcome data", outcome variables were applied to all participants, excluding those who dropped out, and dropouts were noted in the outcome. In terms of the "selective outcome reporting", all studies were evaluated to have low risk of bias, as they included all major outcomes.

\section{Characteristics of Meaning-centered Intervention}

The meaning-centered interventions in the studies were diverse in terms of formality and content. The participants, intervention methods, content, intervention and evaluation timing, measurement tools, and outcome variables of each study are listed in Table 3.

Six studies performed group counselling using combined logotherapy, whereas three performed self-developed logotherapies. Others included life respect education with logotherapy, effects of logotherapy $\mathrm{CD}$ development, palliative care education for hospice nurses using logotherapy techniques, and group art therapy that combined logotherapy. Interventions were performed by the researchers directly or together

Table 2. General Characteristics of Included Studies

$(N=13)$

\begin{tabular}{|c|c|c|}
\hline Variables & Categories & $\mathrm{n}(\%)$ \\
\hline Participants & $\begin{array}{l}\text { Healthy children } \\
\text { Healthy adolescents } \\
\text { Adolescents having cancer }\end{array}$ & $\begin{array}{l}2(15.4) \\
8(61.5) \\
3(23.1)\end{array}$ \\
\hline Publication year & $\begin{array}{l}\text { Up to } 1999 \\
2000 \sim 2009 \\
2010 \sim 2015\end{array}$ & $\begin{array}{l}1(7.6) \\
6(46.2) \\
6(46.2)\end{array}$ \\
\hline Major field of researchers & $\begin{array}{l}\text { Nursing } \\
\text { Education } \\
\text { Counseling psychology } \\
\text { Youth leader }\end{array}$ & $\begin{array}{l}7(53.9) \\
4(30.9) \\
1(7.6) \\
1(7.6)\end{array}$ \\
\hline Setting & $\begin{array}{l}\text { School } \\
\text { Hospital } \\
\text { Church } \\
\text { Community }\end{array}$ & $\begin{array}{l}7(53.9) \\
3(23.1) \\
2(15.4) \\
1(7.6)\end{array}$ \\
\hline Ethical consideration & $\begin{array}{l}\text { Yes } \\
\text { No }\end{array}$ & $\begin{array}{r}3(23.1) \\
10(76.9)\end{array}$ \\
\hline
\end{tabular}


Table 3. Meaning-centered Intervention related Characteristics of Included Studies

\begin{tabular}{|c|c|c|c|c|c|c|c|c|}
\hline \multirow{2}{*}{$\begin{array}{l}\text { Author } \\
\text { (Year) }\end{array}$} & \multirow{2}{*}{$\begin{array}{l}\text { Research } \\
\text { design }\end{array}$} & \multirow[b]{2}{*}{ Participants (n) } & \multicolumn{3}{|c|}{ Intervention } & \multirow[b]{2}{*}{ Control } & \multirow[b]{2}{*}{ Measurements } & \multirow[b]{2}{*}{ Outcomes } \\
\hline & & & Name & $\begin{array}{c}\text { Duration/No. } \\
\text { of session }\end{array}$ & $\begin{array}{l}\text { Min of } \\
\text { Session }\end{array}$ & & & \\
\hline $\begin{array}{l}\text { Kang } \\
\qquad(2006)^{1}\end{array}$ & NCGPPD & $\begin{array}{l}\text { Adolescents having } \\
\text { cancer } \\
\text { (E:9, C6) }\end{array}$ & $\begin{array}{l}\text { Logotherapy } \\
\text { program }\end{array}$ & $\begin{array}{c}10 \text { wks } \\
/ 5\end{array}$ & $7 \sim 8$ & $\begin{array}{l}\text { NPI } \\
\text { Intervention after } \\
\text { post-survey }\end{array}$ & $\begin{array}{l}\text { Suffering scale } \\
\text { PIL test } \\
\text { Spiritual goodness }\end{array}$ & $\begin{array}{l}\text { Suffering* } \\
\text { PIL test* }\end{array}$ \\
\hline $\begin{array}{l}\text { Kang et al. } \\
(2013)^{2}\end{array}$ & NCGPPD & $\begin{array}{l}\text { Early adolescents } \\
\text { having cancer } \\
(\mathrm{E}: 12, \mathrm{C}: 10)\end{array}$ & $\begin{array}{l}\text { Logotherapy } \\
\text { program }\end{array}$ & $\begin{array}{c}1 \sim 2 \text { wks } \\
\text { / } 5\end{array}$ & $30 \sim 40$ & $\begin{array}{l}\text { NPI } \\
\text { Intervention after } \\
\text { post-survey }\end{array}$ & MOL & $\mathrm{MOL}^{*}$ \\
\hline $\begin{array}{l}\text { Kang et al. } \\
(2009)^{3}\end{array}$ & NCGPPD & $\begin{array}{l}\text { Late adolescents } \\
\text { having cancer } \\
\text { (E:22, C:22) }\end{array}$ & $\begin{array}{l}\text { Logotherapy } \\
\text { program }\end{array}$ & $\begin{array}{c}12 \text { wks } \\
/ 5\end{array}$ & 20 & $\begin{array}{l}\text { NPI } \\
\text { Intervention after } \\
\text { post-survey }\end{array}$ & $\begin{array}{l}\text { MOL } \\
\text { Quality of life }\end{array}$ & $\begin{array}{l}\text { MOL }^{*} \\
\text { Quality of life* }\end{array}$ \\
\hline $\begin{array}{l}\text { Lee } \\
\qquad(1997)^{4}\end{array}$ & NCGPPD & $\begin{array}{l}\text { Women working } \\
\text { youth } \\
(\mathrm{E}: 11, \mathrm{C}: 10)\end{array}$ & $\begin{array}{l}\text { Group } \\
\text { counseling }\end{array}$ & $\begin{array}{c}2 \text { wks } \\
/ 10\end{array}$ & $90 \sim 120$ & NR & $\begin{array}{l}\text { PIL test } \\
\text { Job satisfaction }\end{array}$ & $\begin{array}{l}\text { PIL test* } \\
\text { Job satisfaction* }\end{array}$ \\
\hline $\begin{array}{l}\text { Lee } \\
\qquad(2014)^{5}\end{array}$ & NCGPPD & $\begin{array}{l}\text { Middle school } \\
\text { students } \\
(\mathrm{E}: 8, \mathrm{C}: 8)\end{array}$ & $\begin{array}{c}\text { Group art } \\
\text { therapy }\end{array}$ & $\begin{array}{c}2 \text { wks } \\
/ 9\end{array}$ & 90 & NR & $\begin{array}{l}\text { Daily stress } \\
\text { PITR } \\
\text { MOL } \\
\text { MLQ }\end{array}$ & $\begin{array}{l}\text { PITR* }^{*} \\
\text { MLQ* }^{*}\end{array}$ \\
\hline $\begin{array}{l}\text { Lee } \\
\qquad(2015)^{6}\end{array}$ & NCGPPD & $\begin{array}{l}\text { Maladjusted } \\
\text { adolescents in } \\
\text { school } \\
\text { (E:10, C:10) }\end{array}$ & $\begin{array}{l}\text { Group } \\
\text { counseling }\end{array}$ & $\begin{array}{c}5 \text { wks } \\
/ 10\end{array}$ & 100 & NPI & $\begin{array}{l}\text { PIL test } \\
\text { Self-control }\end{array}$ & $\begin{array}{l}\text { PIL test* } \\
\text { Self-control* }\end{array}$ \\
\hline $\begin{array}{l}\text { Jung } \\
\qquad(2003)^{7}\end{array}$ & NCGPPD & $\begin{array}{l}\text { High school } \\
\text { students from } \\
\text { broken families } \\
\text { (E:8, C:8) }\end{array}$ & $\begin{array}{l}\text { Group } \\
\text { counseling }\end{array}$ & $\begin{array}{c}4 \mathrm{wks} \\
/ 8\end{array}$ & 100 & NR & $\begin{array}{l}\text { PIL test } \\
\text { Responsibility }\end{array}$ & $\begin{array}{l}\text { PIL test* } \\
\text { Responsibility* }\end{array}$ \\
\hline $\begin{array}{l}\text { Cho } \\
(2000)^{8}\end{array}$ & NCGPPD & $\begin{array}{l}\text { Adolescents } \\
\text { (E:23, C:24) }\end{array}$ & $\begin{array}{l}\text { Group } \\
\text { counseling }\end{array}$ & $\begin{array}{c}16 \text { wks } \\
\text { / } 10\end{array}$ & $25 \sim 30$ & NR & $\begin{array}{l}\text { PIL test } \\
\text { Self-concept } \\
\text { Self-esteem } \\
\text { Spiritual } \\
\quad \text { wellbeing }\end{array}$ & $\begin{array}{l}\text { PIL test* } \\
\text { Self-concept* } \\
\text { Self-esteem* } \\
\text { Spiritual } \\
\text { wellbeing* }\end{array}$ \\
\hline $\begin{array}{l}\text { Choi } \\
(2000)^{9}\end{array}$ & NCGPPD & $\begin{array}{l}\text { Christian teenager } \\
\text { (E:10, C1:10, } \\
\text { C2:10) }\end{array}$ & $\begin{array}{l}\text { Group } \\
\text { counseling }\end{array}$ & $\begin{array}{c}7 \text { wks } \\
/ 10\end{array}$ & $90 \sim 100$ & $\begin{array}{l}\text { C1: Logotherapy } \\
\text { C2: Self growth } \\
\text { program }\end{array}$ & $\begin{array}{l}\text { PIL test } \\
\text { Life and attitude } \\
\text { of faith }\end{array}$ & $\begin{array}{l}\text { PIL test* } \\
\text { Life and attitude } \\
\text { of faith* }\end{array}$ \\
\hline $\begin{array}{l}\text { Kang et al } \\
(2009)^{10}\end{array}$ & OPPD & $\begin{array}{l}\text { Older school age } \\
\text { children } \\
(50)\end{array}$ & $\begin{array}{l}\text { Development } \\
\text { \& evaluation } \\
\text { MOL CD }\end{array}$ & $\begin{array}{c}5 \text { wks } \\
/ 5\end{array}$ & 50 & None & $\begin{array}{l}\text { Knowledge on } \\
\text { MOL } \\
\text { Attitude on MOL } \\
\text { Practice on MOL }\end{array}$ & $\begin{array}{l}\text { Knowledge on } \\
\text { MOL* } \\
\text { Attitude on } \\
\text { MOL* }^{*} \\
\text { Practice on MOL* }\end{array}$ \\
\hline $\begin{array}{l}\text { Kang et al } \\
\qquad(2013)^{11}\end{array}$ & NCGPPD & $\begin{array}{l}\text { Older school age } \\
\text { children } \\
\text { (E:70, C:72) }\end{array}$ & $\begin{array}{l}\text { Logotherapy on } \\
\text { life respect }\end{array}$ & $\begin{array}{c}3 \text { wks } \\
/ 5\end{array}$ & 40 & $\begin{array}{l}\text { NPI } \\
\text { Post-same } \\
\text { program }\end{array}$ & $\begin{array}{l}\text { Life respect } \\
\text { MOL } \\
\text { Depression }\end{array}$ & $\begin{array}{l}\text { Life respect* } \\
\text { MOL* }^{*} \\
\text { Depression* }\end{array}$ \\
\hline $\begin{array}{r}\text { Kim et al } \\
(2011)^{12}\end{array}$ & NCGPPD & $\begin{array}{l}\text { Nursing college } \\
\text { students } \\
\text { (E:28, C:28) }\end{array}$ & $\begin{array}{c}\text { Palliative care } \\
\text { education }\end{array}$ & $\begin{array}{c}5 \text { wks } \\
/ 10\end{array}$ & 120 & $\begin{array}{l}\text { C: Hospice relief } \\
\text { training only \& } \\
\text { post- } 6 \text { hrs } \\
\text { program }\end{array}$ & $\begin{array}{l}\text { MOL } \\
\text { Attitude to end } \\
\text { of life }\end{array}$ & $\begin{array}{l}\text { MOL* }^{*} \\
\text { Attitude to end } \\
\text { of life* }\end{array}$ \\
\hline $\begin{array}{l}\text { Kim et al } \\
(2000)^{13}\end{array}$ & NCGPPD & $\begin{array}{l}\text { Vocational high } \\
\text { school students } \\
\text { (E:15, C:15) }\end{array}$ & $\begin{array}{l}\text { Group } \\
\text { counseling }\end{array}$ & $\begin{array}{c}5 \text { wks } \\
/ 10\end{array}$ & 100 & NPI & $\begin{array}{l}\text { PIL test } \\
\text { Purpose in life }\end{array}$ & $\begin{array}{l}\text { PIL test* } \\
\text { Purpose in life* }\end{array}$ \\
\hline
\end{tabular}

*Significant finding; NCGPPD=Nonequivalent control group pretest-posttest design; NPI=Not participating in intervention; NR=Not reported; $\mathrm{PIL}=$ Purpose in life; MOL=Meaning of life; PITR=Person in the rain; $\mathrm{MLQ}=$ The meaning in life questionnaire; $\mathrm{OPPD}=\mathrm{One}$ group pretest-posttest design; NPI=Not participating in intervention; $\mathrm{CD}=$ Compact disc. 
with psychological consultants, school nurses, or other trained experts. Sessions were held twice per week in the majority of cases, with most sessions being held between once and twice per week. The total number of interventions was 10 (6 studies), 5 (5 studies), 8 (1 study), and 9 (1 study). Session duration ranged from $7 \sim 8$ minutes to 120 minutes, with 6 being upto 1 hour and 7 being more than an hour.

The topics covered included common logotherapy themes such as freedom, choice, responsibility, suffering, death, finding values of life, discovering life goals and meaning, understanding the preciousness and value of life, empirical values, attitudinal values, establishing attitudes toward life, and taking ownership in life. Regarding the evaluation time of intervention effects, outcome variables were measured before and after interventions in all studies, with 4 studies providing the same intervention to control groups.

\section{Outcome Variables and Effects of Intervention}

Among the 13 studies reviewed, 10 targeted healthy adolescents while 3 worked with adolescents with disease; 11 operated group programs while 2 performed individual ones; and 9 studies adopted logotherapy-only programs while others mixed logotherapy with other methods (Table 4).

Participants' purpose of life was evaluated in eight studies, in which all indicated significant differences before and after intervention. Measurements of meaning of life also indicated substantial deviation between pre- and post-intervention in all 5 studies. Other studies found meaningful enhancements in areas of self-control $(p<.001)$, quality of life $(p=.011)$, self-concept $(p=.008)$, self-esteem $(p=.010)$, spiritual well-being $(p=.026)$, religious life and attitude $(p<.001)$, and reduction in pain $(p<.001)$.
Two of the 13 articles measured the sustainability of meaning-centered interventions, and Kang et al. [14] found that lifeesteem education for elementary school children increased the participants' awareness of respect of life, based on postsurveys held in 1 week and 4 weeks after completion of the intervention $(p<.001, p<.001)$, whereas depression was less prominent in the same surveys $(p<.001, p<.001)$. Other studies revealed that treated adolescents' social relationships [17, 18] had improvements in job satisfaction $(p<.001)$ and sense of responsibility $(p=.004)$ after group logotherapy sessions. In addition, the logotherapy-based hospice and palliative education [19] revealed improved attitudes towards hospice care.

\section{DISCUSSION}

Amid the rising trend of the number of youths who commit suicide and suffer from depression, calls for more social attention to adolescents and their quality of life are gaining attention. Even as the number of studies focusing on the quality of life and happiness of adolescents has increased, research into meaning-centered interventions that could help youth understand the responsibilities and freedoms pertaining to their own life and find true meaning and purpose has been relatively neglected. There has been no research to date that systematically analyzed existing literature regarding meaning-centered interventions to suggest scientific and comprehensive insights of the effects of these interventions. This study is the first to systematically review domestic and overseas studies on meaning-centered intervention to understand common characteristics and effects, to ultimately determine the strategies and methods that can make an intervention more effective.

Database search results showed a total of 9,140 candidates,

Table 4. Categories and Outcomes of Meaning-centered Interventions

$(N=13)$

\begin{tabular}{|c|c|c|c|}
\hline Variables & Categories & $\mathrm{n}(\%)$ & Description (n) \\
\hline & Meaning-centered therapy & $13(100.0)$ & \\
\hline \multirow[t]{2}{*}{ Participants } & Health group & $10(76.8)$ & \\
\hline & Disease group & $3(23.2)$ & $\begin{array}{l}\text { Terminal cancer patient }(1) \\
\text { Early cancer }(1)\end{array}$ \\
\hline \multirow[t]{2}{*}{ Intervention type } & Individual program & $2(15.4)$ & \\
\hline & Group program & $11(84.6)$ & \\
\hline \multirow[t]{2}{*}{ Applied intervention } & Logotherapy only & $9(69.6)$ & \\
\hline & Mixed with logotherapy & $4(30.4)$ & $\begin{array}{l}\text { Life esteemed education (1) } \\
\text { CD development \& evaluation (1) } \\
\text { Hospice \& palliative program (1) } \\
\text { Art therapy (1) }\end{array}$ \\
\hline
\end{tabular}

$\mathrm{CD}=$ Compact disc. 
though only 13 domestic articles were finally opted as appropriate subjects after screening. Four overseas studies initially appeared relevant to meaning-centered intervention, but were eliminated for not having full texts or due to targeting youth suffering from depression. By reviewing the selected literature, it was confirmed that meaning-centered interventions were effective not only on children having cancer, but also on healthy early teens that included middle and high school students, and even college students. All studies, other than the one on program development, had quasi-experimental designs consisting of control groups, supporting the need for randomized control group studies for a more scientific evaluation of the effects.

Overall, $93 \%$ of the studies were carried out by researchers in the field of nursing or educational counselling; over half of the researchers majored in nursing. Nursing is a discipline built on the understanding of human beings and contributes to disease prevention and health enhancement. The imperative of researchers in nursing is to search for different ways to improve subjects' health and treatments [20]. In this regard, nursing research should pay more attention to meaning-centered intervention, which is known to carry positive psychological and social impacts. The evaluation outcomes of the selected literature showed that 12 out of 13 studies had low risk of bias with regards to comparability of participants and confounding variables. On the other hand, by not specifying a detailed study process four studies were deemed to have a high risk of bias in the blinding for outcome assessment domain, with six studies confirmed to have been conducted by the researchers. In future studies, it is necessary to follow a standardized design, such as the Consolidated Standards of Reporting Trials (CONSORT) for randomized comparison studies and the Transparent Reporting of Evaluations with Nonrandomized Designs (TREND) for non-randomized studies [21]. Making clear references to the procedure and outcomes according to its design structure would also help upgrade the quality of the research.

The meaning-centered interventions took place for $1 \sim 2$ weeks in three of the studies, 5 weeks in another three studies, twice per week in five studies, and once per week in three studies. A session typically lasted $90 \sim 120$ minutes, as seen in seven studies. However, comparing how a program's duration and frequency influenced the outcome was difficult due to the inconsistency of variables and measurements among the studies, as well as conducting an in-depth analysis of certain outcome variables. The purpose of meaning-centered intervention programs is to help attendees to understand their responsibility and freedoms pertaining to their own life and to find meaning and purpose of in their lives. Programs often consist of lessons on creativity, experience, attitude, choice, and responsibility, as a means to discover meaning. Learning how to respect life is highly linked to bullying [22], and could be applied to programs to prevent bullying and school violence. The verified effects of meaning-centered intervention in these studies include strengthened purpose of life, meaning of life, self-control, quality of life, self-concept, self-esteem, job satisfaction, sense of responsibility, and religious attitude among participants, as well as advancements in knowledge, attitude, and fulfilment in finding meaning of life, respect of life, and attitude toward death. Depression and pain were also reduced. These results uphold the positive consequences of meaning-centered interventions on adolescents having physical, mental, and social issues.

In more detail, the programs for children having advanced cancer [23], female working children [17], children from broken families [18], and vocational school students [24] taught ways to find one's meaning of life even as they were going through painful times. These programs helped participants develop a stronger purpose of life, sense of responsibility, and self-control. These results confirm that meaning-centered intervention can be an effective nursing intervention to help minimize emotional and spiritual pain during periods of suffering and raise one's quality of life [23]. Meaning-centered intervention was also valuable for the adolescents in Park's study [25], who had attempted suicide under stress, depression, and lack of sense of happiness, leading them to find value and purpose in their lives. Moreover, interventions that teach the meaning of life, purpose of life, responsibility, and self-control will also be applicable to healthy adolescents as they teach how these concepts affect their journey in finding purpose in life.

It is important to decide the content of an intervention based on an understanding of the target participants and their psychological and social problems before organizing a meaning-centered intervention program. For instance, art therapy with logotherapy techniques [26] helps participants establish a positive self-image during the process of artistic expression, visualizing their inner self and experiencing a sense of achievement. This idea supports the results of Lee and Kim's study [27], which shows how positive self-image, experience of sharing, sympathy, and support can help overcome past identities and improve creativity, potential, and sense of responsibility. This method could thus be useful for adolescents who are undergoing an identity crisis and lead them to finding meaning and purpose in their life. Family support is crucial for adolescents because their family perception could extremely affect both their emotion and behavior [1]. None of the programs, however, were designed to involve both the parents and children. Parents' cooperation is critical in helping today's youth find their true meaning and purpose of life, for 
youth to ultimately grow up to be healthy adults. Kim, Cho, and Kim [28] stressed the need for intervention programs that target both parents and their children, especially as parents often tend to put excessive pressure on their child's studies and success. Adolescents who manage to maintain positive and open relationships with their parents are significantly more satisfied with their life than their peers [8]. Educational sessions based on approaches of logotherapy are necessary to guide parents to reflect on the direction and values of their own life.

This study acknowledges limitations in the comprehensiveness of the available review and evaluation of this topic, as all selected studies were conducted in Korea and in a quasi-experimental format. However, this study is the first attempt to probe into the attributes and impacts of meaningcentered interventions targeting adolescents. The domains and strategies examined in this study will thus be able to serve as a foundation for developing future programs that intend to help adolescents establish values and directions in their life.

\section{CONCLUSION}

This study proposed a comprehensive review of the status of previous studies that showcased the benefits of meaning-centered interventions for adolescents and worked to understand the characteristics and effects of such interventions. Potential advantages of meaning-centered interventions during adolescents' adventures in their search of meaning and purpose of life were confirmed.

Despite the positive finding of this study, in terms of methodology there were a few areas that had room for improvement, such as in the observation of research ethics for vulnerable subjects, providing alternative programs for control groups, and applying rigid principles to minimize risk of bias. Overall, however, meaning-centered interventions seemed to work not only for participants that have issues but also for healthy adolescents who are in the midst of creating meaning in their life. As such, the results of this study may be used as a basis for developing appropriate programs that can help enhance adolescents' lives.

Below is a summary of the findings and suggestions from this study:

First, Meaning-centered interventions should be applied to healthy adolescents to confirm its benefits.

Second, Diverse programs and interventions combining logotherapy and other methods should be developed.

Third, Through paired tests on their quality of life, a comparative analysis of responses from parents and children is necessary.

These results should serve as a cornerstone for developing parent education programs to help parents better understand their children's stage of finding meaning and purpose of life and thereby raise healthy adults.

\section{Conflict of interest}

No potential or any existing conflict of interest relevant to this article was reported.

\section{REFERENCES}

1. Park ES, Park IS, Park HR, Shin HS, Kim EK, Jehn WY, et al. Nursing care of children. 4th ed. Seoul: Hyunmoonsa; 2014. p. 257-275.

2. Kang KA, Kim SJ, Song MK, Sim S, Kim SH. Development of an instrument to measure Meaning of Life (MOL) for higher grade primary school children. Journal of Korean Academy of Child Health Nursing. 2007;13(3):308-317.

3. Statistics Korea. 2018 youth statistics posted [Internet]. Daejeon: Statistics Korea; 2018 [cited 2018 march 26]. Available from: http://kostat.go.kr/portal/korea/kor_nw/2/1/index.board?bm ode $=$ read\&aSeq $=367381$.

4. Yeom YS. Report on the international comparison of the 8th child and youth happiness index of 2016 report. International Comparative Study. Korea: Bang Jung Hwan Foundation; 2016 May. Report No.: 2016 Eighth.

5. Frankl VE. Man's search for meaning. 4th ed. Boston, MA: Beacon Press; 2000. p. 67-78.

6. Thomas LP, Meier EA, Irwin SA. Meaning-centered psychotherapy: A form of psychotherapy for patients with cancer. Current Psychiatry Reports. 2014;16(10):488.

https://doi.org/10.1007/s11920-014-0488-2

7. Frankl VE. The will to meaning: Foundations and applications of logotherapy. Expanded ed. New York: Plume; 2014. p. 10-15.

8. Kang KA. Experiences of meaning in life among elementary school students: Content analysis based on major concepts of logotherapy. Child Health Nursing Research. 2017;23(1):37-47.

https://doi.org/10.4094/chnr.2017.23.1.37

9. Shin HJ. A basic survey research for the study of the Quality of Life (QOL): A viewpoint of the low income youth. Journal of Youth Counseling Association. 2016;1(1):39-72.

10. Lee M, Yoo H. The process of searching for my own life of school dropout youths: Focused on youths living at Cheonan-si. The Korea Journal of Youth Counseling. 2013;21(1):341-370.

11. Choi SB, Lee HC, Kim KS. Effects of school adjustment on life satisfaction of multicultural family children and youth. Korean Youth Panel Survey. 2011;2011(1):1-19.

12. Shin SB. Analysis of the determinants of quality of life in Korean adolescents. Journal of Institute for Social Sciences. 2018;29(1):195217. https://doi.org/10.16881/jss.2018.01.29.1.195

13. Ko YN. The relationship between life goals and life satisfaction 
in adolescents: Mediating effects of the search for meaning and the presence of meaning. The Anam Society for the Study of Education. 2017;23(4):161-182.

14. Kang KA, Kim SJ, Song MK, Kim MJ. Effects of logotherapy on life respect, meaning of life, and depression of older school-age children. Journal of Korean Academy of Nursing. 2013;43(1):91-101. https://doi.org/10.4040/jkan.2013.43.1.91

15. Kang KA, Kim SJ, Song MK. Development and evaluation of a finding meaning in life CD program for life-esteemed education of older school-age children. The Journal of Korean Academic Society of Nursing Education. 2011;17(3):487-500.

16. Kim SY, Park JE, Seo HJ, Lee YJ, Son HJ, Jang BH, et al. NECA's guidance for undertaking systematic reviews and meta-analyses for intervention: Version 1.0. 2nd ed. Seoul: National Evidencebased Healthcare Collaborating Agency; 2011. p. 65-92.

17. Lee SO. The effect of logotherapy group counseling on female adolescent worker's job satisfaction [master's thesis]. Daegu: Keimyung University; 1997. p. 1-95.

18. Jeong SY. The effect of logotherapy group counseling program on the improvement of a purpose in life and responsibility in high school students from broken families [master's thesis]. Yeosu: Yosu National University; 2003. p. 1-81.

19. Kim SN, Kim HJ, Choi SO. Effects of hospice and palliative care education program including meaning in life on attitudes toward end-of-life care and meaning in life among nursing college students. The Journal of Korean Academic Society of Nursing Education. 2011;17(3):454-463.

https://doi.org/10.5977/JKASNE.2011.17.3.454

20. Song MK, Bang KS. A systematic review of forest therapy programs for elementary school students. Child Health Nursing Research. 2017;23(3):300-311.

https://doi.org/10.4094/chnr.2017.23.3.300
21. Kim K, Kim JH, Lim KC, Lee KS, Jeong JS, Choe MA, et al. Quality assessment tools and reporting standards in nursing research. Journal of Korean Biological Nursing Science. 2012;14(3):221-230. https://doi.org/10.7586/jkbns.2012.14.3.221

22. Kim SJ, Park YA, Kim SH, Kim HY, Yoo SY, Baek SS, et al. The degree of life-respect and peer bullying in elementary school students. Child Health Nursing Research. 2015;21(1):28-36. https://doi.org/10.4094/chnr.2015.21.1.28

23. Kang KA, Shim JS, Jeon DG, Koh MS. The effect of logotherapy on meaning in life and quality of life of late adolescents with terminal cancer. Journal of Korean Academy of Nursing. 2009;39(6):759-768. https://doi.org/10.4040/jkan.2009.39.6.759

24. Kim HK, Shim KJ. The effects of logotherapy group counseling on the level of the purpose in life of vocational high school students. Journal of Science and Education. 2000;8:105-122.

25. Park E. The influencing factors on suicide attempt among adolescents in South Korea. Journal of Korean Academy of Nursing. 2008;38(3):465-473. https://doi.org/10.4040/jkan.2008.38.3.465

26. Lee JY. The effects of group art therapy using logotherapy on the daily stress and meaning of life of middle school student. Graduate school of Human Care [master's thesis]. Daegu: Daegu Cyber University; 2014. p. 1-100.

27. Lee MS, Kim HJ. The effect of gestalt group art therapy on children's attachment security and school adjustment of the lower graders in low-income group. Korean Journal of Art Therapy. 2013;20 (6):1113-1135.

28. Kim HW, Cho SY, Kim M. Effects of significance of study, pressure for study and success on life satisfaction among adolescents, and the moderating effect of parent-adolescent communication effect of patient-adolescent communication. Journal of Korean Home Economics Association. 2010;48(5):49-60. https://doi.org/10.6115/khea.2010.48.5.049 


\section{Appendix 1. Citations for Studies Included in this Study}

1. Kang KA. Development and effect of semantic therapy program to improve quality of life of adolescent cancer patients. 25th Korean jungshin science symposium; 2006 October 27-28; Military Academy Museum Auditorium. Seoul: Korean Psychological Science Society; 2006. p. 119-130.

2. Kim SJ, Kang KA, Park SJ, Lee MN, Kim YH. The effects of logotherapy on meaning of life of early adolescents with cancer. Asian Oncology Nursing. 2013;13(1):49-57.

https://doi.org/10.5388/aon.2013.13.1.49

3. Kang KA, Shim JS, Jeon DG, Koh MS. The effects of logotherapy on meaning in life and quality of life of late adolescents with terminal cancer. Journal of Korean Academy Nursing. 2009;39(6):759-768. https:// doi.org/10.4040/jkan.2009.39.6.759

4. Lee SO. The effect of logotherapy group counseling on female adolescent worker's job satisfaction [master's thesis]. Daegu: Keimyung University; 1997. p. 1-95.

5. Lee JY. The effects of group art therapy using logotherapy on the daily stress and meaning of life of middle school student. Graduate school of human care [master's thesis]. Daegu: Daegu Cyber University; 2014. p. 1-100.

6. Lee JH. The effects of a logotherapy group counseling program on the purpose-in-life and self-control of the maladjusted adolescents in school [master's thesis]. Daegu: Daegu Haany University; 2015. p. 1-120.

7. Jeong SY. The effects of logotherapy group counseling program on the improvement of a purpose in life and responsibility in high school students from broken families [master's thesis]. Yeosu: Yosu National University; 2003. p. 1-81.

8. Cho HS. The effects of logotherapeutic group counseling on purpose in life, self-concept, self-esteem and spiritual wellbeing of adolescence [master's thesis]. Busan: Kosin University; 1999. p. $1-68$.

9. Choi MO. The effects of logotherapy group counseling on the purpose in life and life of faith of christia teenager [master's thesis]. Daegu: Keimyung University; 2000. p. 1-70.

10. Kang KA, Kim SJ, Song MK. Development and evaluation of a finding meaning in life $\mathrm{CD}$ program for life-esteemed education of older school-age children. The Journal of Korean Academic Society of Nursing Education. 2011;17(3):487-500.

11. Kang KA, Kim SJ, Song MK, Kim MJ. Effects of logotherapy on life respect, meaning of life, and depression of older school-age children. Journal of Korean Academy of Nursing. 2013;43(1):91-101. https://doi.org/10.4040/jkan.2013.43.1.91

12. Kim SN, Kim HJ, Choi SO. Effects of hospice and palliative care education program including meaning in life on attitudes toward end-of-life care and meaning in life among nursing college students. The Journal of Korean Academic Society of Nursing Education. 2011;17(3):454-463. https://doi.org/10.5977/JKASNE.2011.17.3.454

13. Kim HK, Shim KJ. The effects of logotherapy group counseling on the level of the purpose in life of vacational high school students. Journal of Science and Education. 2000;8:105-122. 